\title{
PELAKSANAAN PEMBELAJARAN \\ IPS BERBASIS KEUNGGULAN LOKAL DALAM \\ UPAYA MEMBANGUN KETERAMPILAN SOSIAL MAHASISWA PENDIDIKAN IPS
}

\author{
Aisyah Nur Sayidatun Nisa (aisyah8816@mail.unnes.ac.id) \\ Fredy Hermanto (fredyunnes@gmail.com) \\ Rudi Salam (rudiunnes@gmail.com) \\ Pendidikan IPS FIS Universitas Negeri Semarang
}

\begin{abstract}
This research is an Sosial Studies-based learning local excellence. Through learning the local excellence, specific goals to be achieved are expected sosial intelligence of students will be better and make positive contribution to students of Sosial Studies education in terms of gaining as understanding, monitor learning, interaction, participation and to develop new relationships.

This is a qualitative research, with a case study design, the subject is a students and lecturer of Sosial Studies Education Departement, Sosial Sciences Faculty, Semarang University. This analysis using qualitative analysis, with interactive analysis, presented data with tabular from and the interpretation, in order to obtain the appropriate conclusions. Learning implementation went smootly, got a very good response, can explore social skill of the students, learning inside and outside of learning.
\end{abstract}

Keywords : Social Skill, Social Studies-based learning, Local Excellence.

\begin{abstract}
Abstrak
Penelitian ini merupakan pembelajaran IPS yang berbasis keunggulan lokal. Melalui pembelajaran berbasis keunggulan lokal, tujuan khusus yang ingin dicapai diharapkan kecerdasan sosial mahasiswa akan lebih baik dan memberikan kontribusi positif pada mahasiswa pendidikan IPS dalam hal memperoleh pemahaman, memonitor belajar, meningkatkan interaksi, dan partisipasi serta mengembangkan hubungan baru diantara mahasiswa.

Penelitian ini merupakan penelitian kualitatif dengan desain studi kasus. Subyek penelitian ini adalah mahasiswa dan dosen program studi Pendidikan IPS Fakultas Ilmu Sosial Universitas Negeri Semarang. Analisis data menggunakan analisis data kualitatif dengan desain análisis interaktif dimana data akan disajikan dalam bentuk tabel disertai interpretasi sehingga diperoleh suatu kesimpulan yang memadai. Pelaksanaan pembelajaran berjalan lancar, respon mahasiswa dalam pembelajaran hampir semua baik begitu juga dengan dosen, responnya sangat baik, memperlihatkan keterampilan sosial yeng dimiliki oleh mahasiswa, baik dalam pembelajaran ataupun diluar pembelajaran.
\end{abstract}

Kata Kunci: Keterampilan Sosial, Pembelajaran IPS, Keunggulan Lokal 


\section{Pendahuluan}

Pendidikan mempunyai peran yang sangat penting, sesuai yang disampaikan dalam Undang-Undang No. 20 Tahun 2003 mengenai sistem pendidikan nasional yang unyi "pendidikan adalah usaha sadar da. terencana untuk mewujudkan suasana belajar dan proses pembelajaran agar mahasiswa secara aktif mengembangkan potensi dirinya untuk memiliki kekuatan spiritual, keagamaan, pengendalian diri, kepribadian, kecerdasan, akhlak mulia, serta ketrampilan yang diperlukan dirinya, masyarakat, bangsa dan egara". Undan - undang menunjukkan bahwa pendidikan peran yang penting dalam mengembangkan kecerdasan manusia baik kecerdasan intelektual atau Intelligence Quotient (IQ), kecerdasan emosional atau Emotional Quotient (EQ), dan kecerdasan spiritual atau Spiritual Quotien (SQ).

Penerapan sistem pendidikan nasional sekarang, membuat mahasiswa hanya mengejar nilai (indeks prestasi) dan berpikir bagaimana caranya agar dapat lulus dengan cepat. Sistem pendidikan seperti itu menekan mahasiswa, membuat mahasiswa terkurung dalam lingkaran kekakuan. Kegiatan perkuliahan pada umunya hanya berkiprah pada kajian teori-teori saja, tidak banyak desain perkuliahan yang sampai menjangkau kepada ranah kognitif, afektif, psikomotorik. Proses pembelajaran seperti itu tentu akan menghasilkan lulusan yang memiliki kecerdasan dan kepedulian sosial yang rendah. Sehingga membangun kecerdasan sosial mahasiswa sangat penting, karena mahasiswa yang mempunyai kecerdasan sosial yang tinggi akan peka dan kritis melihat realitas sosial. Apalagi jika realitas sosial yang berkembang memberi kebaikan bagi manusia, menanam benih moralitas, membangun kualitas hidup manusia, memberi kontribusi yang terbaik dari kemampuan dirinya untuk memberikan kepada realitas sosial itu.
Ditinjau dari kenyataan lapangan, banyak anak dan pemuda yang tidak belajar keterampilan sosial yang dibutuhkan untuk hidup dan bekerja sama dengan orang lain sebelum mereka masuk ke sekolah. Menurut Richard (2008:28) ketrampilan-ketrampilan yang ditemukan kurang pada banyak anak dan pemuda termasuk ketrampilan berbagi, ketrampilan berpartisipasi, dan ketrampilan berpartisipasi. Ada empat keterampilan dasar yang mesti dikembangkan dalam kecerdasan sosial yaitu mengorganisi kelompok, merundingkan pemecahan masalah, menjalin hubungan, dan menganalisis sosial. Keempat ketrampilan dasar yang dikembangkan dalam kecerdasan sosial ini, sesuai dengan tujuan pembelajaran IPS.

Pada penelitian ini merupakan pembelajaran IPS yang berbasis keunggulan lokal. Diharapkan, melalui pembelajaran berbasis keunggulan lokal, mahasiswa didorong untuk mencintai tanah kelahirannya, berjuang untuk membesarkannya, dan gigih mengembangkan semua potensinya. Melalui pembelajaran berbasis keunggulan lokal ini pula, diharapkan mahasiswa mencintai tanah kelahirannya, percaya diri menghadapi masa depan, dan bercita-cita mengembangkan potensi lokal, sehingga daerahnya bisa berkembang pesat seiring dengan tuntutan era globalisasi dan informasi.

Berdasarkan uraian latar belakang yang telah disampaian, maka peneliti akan mengambil judul penelitian "Pelaksanaan Pembelajaran IPS Berbasis Keunggulan Lokal Dalam Upaya Membangun Keterampilan . al Mahasiswa Pendidikan IPS". Tujuan penelitian ini: 1) Untuk mendeskripsikan pelaksanaan pembelajaran IPS berbasis keunggulan lokal dalam upaya membangun keterampilan sosial mahasiswa Pendidikan IPS, 2) Untuk mengetahui faktor-faktor yang mendukung dan menghambat dalam upaya membangun keterampilan sosial mahasiswa Pendidikan IPS melalui pembelajaran IPS berbasis keunggulan lokal. 


\section{Metode}

Jenis penelitian ini adalah penelitian dengan menggunakan metode atau pendekatan kualitatif. Teknik pengumpulan data yang peneliti gunakan adalah wawancara/interview, observasi, dokumentasi dan catatan lapangan. Pemastian keabsahan data, dalam penelitian ini menggunakan triangulasi data (data triangulasi) dan triangulasi peneliti (investigator triangulasi). Model analisis yang digunakan dalam penelitian ini adalah Analisis Model Interaktif, artinya analisis ini dilakukan dalam bentuk interaksi pada tiga komponen tersebut yang digambarkan sebagai berikut.

Subyek penelitian dalam penelitian kali ini adalah mahasiswa dan dosen program studi Pendidikan IPS Fakultas Ilmu Sosial Universitas Negeri Semarang. Penelitian mengenai Membangun Keterampilan Sosial Mahasiswa Pendidikan IPS melalui Pembelajaran IPS Berbasis Keunggulan Lokal dilaksanakan di program studi Pendidikan IPS Fakultas Ilmu Sosial Universitas Negeri Semarang dengan alamat Jalan Raya Sekaran, Gunungpati 50229 Kabupaten Semarang. Penelitian dilakukan di program studi Pendidikan IPS Fakultas Ilmu Sosial Universitas Negeri Semarang dalam waktu 1 tahun.

\section{Pembahasan}

1. Pelaksanaan Pembelajaran IPS Berbasis pembelajaran. Selain itu, dosen juga Keunggulan Lokal dalam Upaya menetapkan sikap dan keterampilan sosial

\section{Membangun Keterampilan Sosial Mahasiswa Pendidikan IPS.}

Pelaksanaan pembelajaran di program studi Pendidikan IPS semester Genap 2014/2015 untuk mahasiswa semester II mata kuliah Pendidikan Karakter menggunakan model pengajaran team teaching, ini terlihat dalam SAP mata kuliah Pendidikan Karakter dimana dosen pengampu mata kuliah Pendidikan IPS tersebut terdiri dari dua dosen, yaitu Dr. Eko Handoyo M.Si dan Eta Yuni Lestari S.Pd., MH. Dalam pelaksanaan perkuliahannya Pembelajaran di program studi
Pendidikan IPS khususnya mata kuliah

Pendidikan Karakter dengan menyisipkan keunggulan lokal yang dimiliki Indonesia, khususnya di Semarang.

Pelaksanaan pembelajaran di program studi Pendidikan IPS sudah baik yaitu dengan memperhatikan langkah-langkah yang benar, yaitu mengenai perencanaan pembelajaran yang dilanjutkan dengan pelaksanaan pembelajaran/kegiatan pembelajaran dan diakhiri dengan evaluasi/penilaian.

\section{a. Perencanaan Pembelajaran}

Perencanaan pada mata kuliah Pendidikan Karakter sudah baik, ini terlihat dari aktivitas yang dilakukan oleh dosen mata kuliah Pendidikan IPS yaitu dengan membuat SAP dan Bahan Ajar Pendidikan Karakter. Perencanaan pembelajaran yang baik dan optimal sebaiknya sebelum perkuliahan dimulai di awal semester, SAP harus sudah tersusun rapi sesuai dengan format ISO, sehingga agar SAP sudah siap untuk menjadi bahan acuan dalam proses perkuliahan, maka perlu adanya koordinasi tim penyusun SAP yang baik. SAP yang baik adalah SAP yang disusun secara team teaching oleh dosen mata mata kuliah.

Kegiatan perencanaan ini dosen mempertimbangkan dan menetapkan target pembelajaran yang ingin dicapai dalam yang diharapkan dikembangkan dan diperhatikan oleh mahasiswa selama berlangsungnya pembelajaran. Dosen dalam merancang program pembelajaran harus mengorganisasikan materi dan tugas-tugas mahasiswa yang mencerminkan keterampilan sosial mahasiswa. Keterampilan Sosial adalah perilaku-perilaku yang mendukung kesuksesan hubungan sosial dan memungkinkan individu untuk bekerja bersama orang lain secara efektif (Richard, 2008:28). 


\section{b. Pelaksanaan Pembelajaran}

Pelaksanaan pembelajaran pada Prodi Pendidikan IPS selama satu semester berlangsung dalam jumlah 16 kali tatap muka. Selama perkuliahan mahasiswa Pendidikan IPS terlihat aktif mengikuti kegiatan pembelajaran yang berlangsung. Saat dosen memberikan penjelasan mereka terlihat memperhatikan secara sekasama, meskipun ada satu dua mahasiswa yang terlihat tidak fokus terhadap materi yang diberikan oleh dosen. Beberapa mahasiswa Pendidikan IPS menyimak dan menulis apa yang dijelaskan oleh dosen, dan ada juga yang belum sepenuhnya konsentrasi terhadap pembelajaran yang sedang berlangsung.

Kesempatan berbicara mahasiswa mengemukakan tergolong kedalam berkomunikasi dan keterampilan berperan dalam kelompok. Ini sesuai dengan teori

Azzet. Azzet (2011:64-70) mengembangkan karya dari Shapiro yang berjudul How To Raise a Child with a High EQ menyampaikan bahwa setidaknya ada lima Keterampilan Sosial yang perlu dilatihkan pada anak, yaitu keterampilan berkomunikasi, ketrampilan dalam membuat humor, keterampilan menjalin persahabatan, ketrampilan berperan dalam kelompok, dan ketrampilan bersopan santun dalam pergaulan.

\section{c. Penilaian/Evaluasi}

Penilaian yang dilakukan oleh dosen adalah dengan penilaian berbasis kelas. Penilaian kelas dilakukan, baik dalam bentuk tes tertulis (paper and pencil test), hasil karya (product), maupun pengumpulan kerja siswa (portofolio). Evaluasi/penilaian yang dilakukan oleh dosen pengampu mata kuliah Pembelajaran mengacu pada pedoman yang telah dibuat secara bersama-sama dalam team teaching tersebut. Dalam menilai, dosen pengampu menggunakan model penilaian berbasis kelas, dimana dosen pengampu masih pengetahuan (kognitif), ranah sikap (afektif), dan ranah ketrampilan (psikomotorik). Yaitu dengan penilaian kerja (performance), penilaian penugasan (project), penilaian hasil kerja (product) dan penilaian sikap (Masnur 2007).

Perkuliahan di program studi Pendidikan IPS Universitas Negeri Semarang dalam penilaiannya menggunakan penilaian berbasis kelas dengan perincian adanya penilaian kerja, penugasan, hasil kerja, dan penilaian sikap.

Tetapi dalam pelaksanaannya untuk kelengkapan format penilaiannya setelah peneliti observasi ternyata belum lengkap untuk semua format penilaiannya. Untuk penilaian kerja, penugasan dan hasil kerja sudah terlihat di SAPnya. Ternyata setelah pelaksanaan pembelajaran IPS berbasis keunggulan lokal mahasiswa lebih termotivasi lagi untuk lebih memahami konsep-konsep yang ada, sehingga hasil pembelajaranpun lebih optimal dan terlihat keterampilan sosial mahasiswa khususnya terkait dengan keterampilan berkomunikasi, keterampilan membuat humor, ketarampilan menjalin persahabatan, keterampilan berperan dalam kelompok dan keterampilan bersopan santun dalam pergaulan. Sehingga nilai akhir mahasiswa menjadi lebih bagus.

Pelaksanaan pembelajaran IPS yang baik, efektif dan efisien sebenarnya tidaklah sulit, kembali lagi ini tergantung dari situasi dan kondisi, baik itu dosennya, mahasiswanya, sarana prasarananya ataupun lingkungan perkuliahannya. Selain itu pelaksanaannya sendiri harus terarah dengan baik, yaitu mengenai proses pembelajarannya, seharusnya pada awal sebelum perkuliahan selesai yang harus dilakukan oleh dosen adalah merancang rencana program pembelajaran. Pada langkah ini dosen mempertimbangkan dan menetapkan target pembelajaran yang ingin dicapai dalam pembelajaran. Selain itu, dosen juga menetapkan sikap dan keterampilan sosial yang diharapkan dikembangkan dan memperhatikan tiga ranah, yaitu ranah 
diperhatikan oleh mahasiswa selama lingkungan. Anak-anak yang dibesarkan berlangsungnya pembelajaran. dalam keluarga yang tidak harmonis (broken

Dosen dalam merancang program home) di mana anak tidak mendapatkan pembelajaran harus mengorganisasikan materi kepuasan psikis yang cukup maka anak akan dan tugas-tugas mahasiswa yang sulit mengembangkan ketrampilan sosialnya. mencerminkan sistem kerja dalam kelompok Ini sesuai dengan hasil studi Davis dan kecil. Setelah semua persiapan selesai, dilanjutkan dengan dosen merancang lembar observasi yang akan digunakan untuk ' orsythe (Mv'tadin, 2006).

Mahasiswa pendidikan IPS sebagian besar memiliki keluarga yang harmonis. mengobservasi kegiatan mahasiswa dalam Namun demikian konflik-konflik keluarga belajar secara bersama-sama dalam kelompokkelompok kecil. Dosen hanya menjelaskan pokok-pokok materi dengan tujuan mahasiswa mempunyai wawasan dan orientasi yang memadai tentang materi yang diajarkan. Pada saat dosen selesai menyampaikan materi, langkah berikutnya adalah menggali pengetahuan dan pemahaman siswa tentang materi pelajaran berdasarkan apa yang telah diberikan. Baru kemudian dosen melakukan observasi kelas diasaat proses pembelajaran berlangsung, dalam melakukan observasi terhadap kegiatan mahasiswa, dosen mengarahkan dan membimbing mahasiswa, baik secara individual maupun kelompok, baik dalam memahami materi maupun mengenai sikap dan perilaku mahasiswa selama kegiatan belajar berlangsung, sehingga dalam membangun keterampilan sosial mahasiswa bisa optimal. Selain itu dosen juga berkewajiban secara periodik memberikan layanan kepada mahasiswa, baik secara individual maupun secara klasikal. Pemberian pujian dan kritikan dari dosen juga akan membangun kreativitas mahasiswa dalam bekerja berkelompok. tetap ada di dalam kehidupan keluarga mereka. Faktor usia menjadi salah satu penyebab utama timbulnya konflik-konflik tersebut. Mahasiswa IPS masih dalam kategori usia remaja, rasa ingin tahu dan ego yang besar menyebabkan munculnya perbedaan pandangan antara mereka dengan keluarga.

Konflik-konflik yang timbul dapat diatasi tanpa menimbulkan konflik lain yang lebih besar. Komunikasi yang baik mereka jalin sebagai sebuah upaya dalam memecahkan konflik yang terjadi. Adanya perbedaan tempat tinggal antara keluarga dengan mahasiswa Pendidikan IPS karena sebagian mahasiswa Pendidikan IPS tinggal di kost, mempengaruhi komunikasi mereka. Tidak bertatap muka secara langsung dengan keluarga mempengaruhi cepat atau lambatnya penyelesaian konflik.

\section{b. Lingkungan}

Selain keluarga faktor lain yang mempengaruhi keterampilan sosial adalah lingkungan, kepribadian dan kemampuan penyesuaian diri. Secara umum Lingkungan yang dihadapi oleh mahasiswa pendidikan IPS terbagi menjadi tiga bagian, yakni:

2. Faktor-faktor yang Mempengaruhi Lingkungan kampus, lingkungan kos, dan Keterampilan Sosial Mahasiswa

\section{a. Keluarga}

Keluarga merupakan tempat pertama dan utama bagi anak dalam mendapatkan pendidikan. Kepuasan psikis yang diperoleh anak dalam keluarga akan sangat menentukan bagaimana ia akan bereaksi terhadap

lingkungan keluarga. Tiga lingkungan itu yang memiliki porsi paling besar dalam kehidupan mahasiswa Pendidikan IPS. Lingkungan kampus merupakan lingkungan akademik, mereka berada di kampus selama lima hari dalam seminggu. Pengaruh budaya kampus mempengaruhi mereka dalam bersikap dan berperilaku. Karakter mereka terbentuk sesuai 
dengan budaya yang ada di dalam kampus.

Lingkungan kos merupakan lingkungan

yang punya pengaruh besar dalam pengembangan karakter mahasiswa pendidikan IPS karena lingkungan kos sebagai lingkungan tempat tinggal mereka sehari-hari.

Keberagaman penghuni kos yang datang dari daerah yang berbeda, karakter penghuni kos yang berbeda-beda mempengaruhi cara berpikir dan bertingkah laku mereka seharihari. Lingkungan keluarga sebagai lingkungan inti dijadikan dasar oleh mahasiswa Pendidikan IPS dalam menghadapi lingkungan di luar. Karakter yang sudah di dapat dari lingkungan keluarga dijadikan pedoman dalam hidup di lingkungan yang lain. Sehingga lingkungan sangat berpengaruh terhadap pembentukan karakter mahasiswa dalam mewujudkan keterampilan sosial.

Menurut Sanjaya (2008) dilihat dari dimensi lingkungan ada dua faktor yang dapat memengaruhi proses pembelajaran, yaitu faktor organisasi kelas dan faktor iklim sosialpsikologis. Untuk menciptakan lingkungan masyarakat yang optimal baik secara fisik maupun mental, dengan cara menciptakan suasana kelas yang yang nyaman, suasana hati yang gembira tanpa tekanan maka dapat memudahkan mahasiswa memahami materi pelajaran. Pengaturan kelas yang baik merupakan langkah pertama yang efektif untuk mengatur pengalaman belajar siswa secara keseluruhan.

Begitu juga dengan adanya branding konservasi yang dimiliki oleh Unnes, memang tidak diperbolehkannya ada AC didalam ruang kelas. Hal ini yang membuat suasana belajar didalam kelas menajdi tidak nyaman karena panas. Tidak adanya kipas angin juga membuat kelas kurang dirasa nyaman. Mensiasatinya dengan membuka pintu dan jendela berakibat masuknya suara-suara dari luar yang dapat mengganggu proses pembelajaran. Tetapi banyak sisi positif dari Unnes yang berciri konservasi, begitu juga dengan Fakultas Ilmu Sosial dengan slogan
FIS Peduli dengan mengedepankan kecerdasan sosial dan keterampilan sosial. Jadi sangat mendukung dalam pembentukan keterampilan sosial mahasiswa melalui pembelajaran berbasis keunggulan lokal.

\section{c. Kepribadian dan Kemampuan Menyesuaikan diri mahasiswa}

Kesiapan mahasiswa dan dukungan dari pihak luar, sehingga memudahkan kita untuk beradaptasi. Dosen sudah berupaya untuk membentuk keterampilan sosial mahasiswa melalui proses pembelajaran, akan tetapi kembali lagi kepada individu-individu, ada yang dengan cepat terbentuk keterampilan sosialnya ada pula yang lambat. Keinginan serta motivasi yang berbeda yang menyebabkan timbulnya perbedaan tersebut. Keterampilan sosial mahasiswa pendidikan IPS terlihat sudah dimiliki. Hal tersebut didapat dari kesimpulan wawancara kepada mahasiswa. Mereka dalam berkomunikasi menggunakan bahasa yang sopan, dapat melihat situasi kapan harus serius kapan saatnya bercanda. Keterampilan ini di dapat berdasarkan pengalaman mereka dalam hidup sehari-hari dan juga dari hasil pembinaan yang dilakukan dalam proses pembelajaran.

\section{Simpulan}

Pelaksanaan Pembelajaran IPS berbasis keunggulan lokal dalam upaya membangun keterampilan sosial mahasiswa Pendidikan IPS sudah baik, yaitu terlihat dengan adanya suatu proses yang terencana dengan baik, yaitu mengenai kegiatan perencanaan pembelajaran dengan pembuatan Silabus, SAP, kontrak perkuliahan dan bahan ajar yang berbasis keunggulan lokal. Yang kemudian dilanjutkan dengan pelaksanaan pembelajaran dan diakhiri dengan evaluasi/penilaian. Pada pelaksanaan pembelajaran ada beberapa faktor yang mempengaruhi dalam upaya membangun keterampilan sosial mahasiswa berbasis keunggulan lokal, diantaranya keluarga dan 
lingkungan, kepribadian dan penyesuaian diri. Pelaksanaan pembelajaran IPS Berbasis Keunggulan Lokal dalam Upaya Membangun Keterampilan Sosial Mahasiswa Pendidikan IPS supaya optimal maka harus lebih teliti lagi mengenai kegiatan perencanaan pembelajaran yang dilanjutkan dengan pelaksanaan pembelajaran dan diakhiri dengan evaluasi/penilaian, serta dengan tetap memperhatikan faktor-faktor yang mempengaruhi munculnya keterampilan sosial pada mahasisa Pendidikan IPS

\section{DAFTAR PUSTAKA}

2011. Pendidikan Ilmu

Pengetahuan Sosial. Semarang: Widya Karya

Arends. Richard I. 2008. Learning To Teach 2. Terjemahan Helly Prajitno Soetjipto dan Sri Mulyantini Soetjipto. Yogyakarta: Pustaka Pelajar

Arifin, Syamsir. 1991. Kamus Sastra Indonesia. Jakarta: Balai Pustaka

Arikunto, Suharsimi. 2006. Prosedur Penelitian Suatu Pendekatan Praktik. Jakarta: PT. Rineka Cipta

.mani, Jamal Ma'mur. 201? Pendidikan Berbasis Keunggulan Lokal. Yogyakarta: DIVA Press

Aqip, Zainal. dkk. 2010. Penelitian Tinddakan Kelas. Bandung: Yrama Widya

Azzet, Akhmad Muhaimin. 2011. Mengembangkan Kecerdasan Sosial Bagi Anak. Yogyakarta: Kata Hati
Black, James A. Dean J Champion. 1992. Metode dan Masalah Penelitian Sosial Bandung: Refika Aditama

Denzin, Norman K., dan Yvonna S. Lincoln. 1994. Handbook of Qualitative Research. Thousand Oaks, London: Sage

Huda, Miftahul. 2013. Model-Model Pengajaran dan Pembelajaran: IsuIsu Metodis dan Paradigmatis. Yogyakarta: Pustaka Pelajar

Mahmud. 2011. Metode Penelitian Pendidikan. Bandung: Pustaka Setia

Miles, Matthew B., dan A. Michael Huberman. 1992. Analisis Data Kualitatif. Terjemahan Tjetjep Rohendi Rohidi. Jakarta:Universitas Indonesia Press

Moleong, L.J. 2002. Metodologi Penelitian Kualitatif, cet. VII. Bandung: PT. Remaja Rosda Karya.

Nur Sasongko, Rambat. 2001. Model Pembelajaran Aksi untuk Pengembangan Nilai-Nilai dan Keterampilan Sosial: Studi Eksperimental pada Mahasiswa Peserta Kuliah Kerja Nyata Universitas Bengkulu. Disertasi. Bandung: UPI.

Poerwasarminta, W.J.S. 1976. Kamus Bahasa Indonesia. Pustaka Jakarta: Balai

Sapriya. 2009. Pendidikan IPS Konsep dan Pembelajaran. Bandung: PT Remaja Rosdakarya Offset.

Soemantri, Muhammad Numan. 2001. Menggagas Pembaharuan Pendidikan 
IPS. Bandung: PT. Remaja Rosda Karya

Solihatin, Etin. 2005. Cooperative Learning Analisis Model Pembelajaran IPS SD. Jakarta: Bumi Aksara.

Sugiyono. 2008. Metode Penelitian Kuantitatif, Kualitatif, Kombinasi (Mixed Methods). Bandung: Alfabeta

Sutopo, HB. 2007. Metodologi Penelitian

Kualitatif: Dasar, Teori, dan Terapannya dalam Penelitian. Surakarta: UNS Press.

Tim Pustaka Yustisia. 2007. Panduan Lengkap KTSP (Kurikulum Tingkat Satuan Pendidikan) SD/MI, SMP/MTs, dan SMA/SMK.

Yogyakarta: Pustaka Yustisia.
Undang-Undang tentang Pemerintahan Daerah. No.22 tahun 1999

Undang-Undang tentang Sistem Pendidikan Nasional. No.20 tahun 2003

Wiryohandoyo, Soedarno dkk.1998. Pendidikan Ilmu Sosial. Semarang: IKIP Semarang

Zuliana \& Bintoro. 2013. Desain Pembelajaran Matematika Realistik di Sekolah Dasar Berbasis Keunggulan Lokal Kudus (Suatu Design Research Dalam Pembelajaran Matematika Sd Di Kabupaten Kudus). Lapora Penelitian Dosen Pemula Dikti. 